\title{
National Competency-Based Teacher Standards and Teaching Effectiveness
}

\author{
Michelle Pamela Gultiano-Ansayam \\ Bukidnon State University \\ Malaybalay City Bukidnon Philippines
}

\begin{abstract}
The study was conducted to assess the competency and teaching effectiveness of teachers. It aimed at determining the level of teachers' competency based on the National Competency-Based Teacher Standards in terms of social regard for learning, learning environment, diversity of learners, curriculum, planning, assessing and reporting, community linkages, and personal growth and professional development. It ascertained the level of teaching effectiveness according to commitment, knowledge of the subject, teaching for independent learning, and management of learning. It correlated teaching effectiveness and competency. Also, it identified the variable that singly or in combination best predicts the teaching effectiveness. Employing descriptive-correlational research design, it was delimited to the ninety (90) teacher-participants in Impasugong I District, twenty-nine (29) teacherparticipants in Impasugong II District and sixty-nine (69) teacher-participants in Sumilao District teaching across Grades 1 to VI. Mean, percentage, the Pearson $r$ analysis, and stepwise regression analysis were applied. Among the seven domains of NCBTS, community linkages got the highest aggregate value of 3.88 described which described teachers as proficient. In all domains, the teachers were also found proficient. Results revealed that $0.5 \%$ of teachers were fairly effective, $19.15 \%$ were satisfactory, $68.09 \%$ were very satisfactory, and $12.23 \%$ were outstanding. Teaching effectiveness revealed a significant correlation with all the domains of NCBTS. Teachers' competency in the curriculum was the sole significant predictor of teachers' teaching effectiveness.
\end{abstract}

Keywords:- National Competency-Based Teachers Standards, teaching effectiveness

\section{INTRODUCTION}

Achievement is accounted for the teachers who are the main agents of the educative process for it implicitly assesses the performance of the teachers. It may only be one of the factors affecting the overall quality of education in a particular school. For this reason, the teachers to competent and effective in teaching their clientele are peremptory.

It is one of the school performance indicators which reports the achievement of the learners through the National Achievement Test (NAT) conducted every academic year. According to Lapus, the national target set by the National Education Testing and Research Center
(NETRC) is 75\% (Tubeza, 2010). As recorded, the National Achievement Test results in 2014 reveal a Mean Percentile Score (MPS) of $68.20 \%$ (Mateo, 2014).

Agencies that support the development of education initiate ways to be able to help the teachers. National competency as a project of the Research Center for Teachers Quality (TCTQ) is funded by the Department of Foreign Affairs and Trade Australian Aid Program (DFAT/AAP) through the efforts of the University of New England National Research Centre in partnership with the Philippine Normal University. It aims to prepare a set of developmental professional teacher standards that reflect the teacher quality requirements congruent with the $\mathrm{K}$ to 12 Reform. These standards would apply to pre-service and inservice teachers and provide a basis for enhancing the profession. The standards are intended to describe the key features of teachers' readiness upon entry into the profession and progression through different stages of their teaching career. National Competency-Based Teacher Standards (NCBTS), as part of the Basic Education Sector Reform Agenda (BESRA), is designed. It is an integrated theoretical framework that defines the different domains of effective teaching, where effective teaching means being able to help all types of students learn the different learning goals in the curriculum (NCBTS, 2013).

Labrador (2010), during her office as Department of Education undersecretary, said in an open letter that the Department of Education needed to determine the strengths and needs of teachers to find ways on how to address them. It was added that all teachers should take personal responsibility for their personal growth. Thus, this study was carried out to answer the following questions:

What is the level of teachers' competency based on the National Competency-Based Teacher Standards in terms of social regard for learning, learning environment, diversity of learners, curriculum, planning, assessing and reporting, community linkages, and personal growth and professional development?

$>$ What is the level of teaching effectiveness of teachers according to commitment, knowledge of the subject, teaching for independent learning, and management of learning?

$>$ What is the relationship between teaching effectiveness and National Competency-Based Teacher Standards?

$>$ Which of the variables singly or in combination, best predicts teaching effectiveness? 


\section{LITERATURE REVIEW ON NATIONAL COMPETENCY-BASED TEACHER STANDARDS AND TEACHING EFFECTIVENESS}

\section{Social Regard for Learning}

Plantilla as cited by Estojero (2014) once said "What the teachers, are the students". It is since they are the role models of the students in and out of the classroom. They need to have the values and attitudes as role models to the learners. Teachers must always have high social regard for learning. According to Pa-alisbo (2017), the teaching profession is a challenging vocation that calls for highly skilled and performing individuals. The intricacies of work coupled with the demanding needs of the times have posed challenges to the teachers. The new teaching paradigm of DepEd on international, national, and local competitiveness is the implementation of the $\mathrm{K}$ to 12 Basic Education Program to all public elementary and secondary schools in the Philippines by President Aquino III.

\section{$>$ Learning Environment}

Bush as cited by Harrington and Holub (2006) stated that the government must speak for disadvantaged children who have unheard and overlooked. They are the children who were hidden behind the average and shuffled from class to class, grade to grade, without receiving the attention they needed and deserved. Salandandan (2006) added that the learning environment must be orderly and conducive to learning. Cognizant of a possible continuum of interaction that could influence every teaching-learning episode, there should be an appropriate and suitable plan of action that is directed towards learning objectives intended to assist strategizing the flawless unfailing execution of manifold classroom activities. The crucial decision on which and how to employ each rests upon the teacher who is familiar with conducive to the learning environment, with her students' characteristics, and mindful of her technique.

The Kentucky Department of Education (2013) reported having worked in teams to develop Characteristics of Highly Effective Teaching and Learning as supports focused on the instructional core. The research has established a learning climate as one of its components. Accordingly, learning climate is a safe environment supported by the teacher with high, clear expectations, and positive relationships are fostered and active learning is promoted.

\section{$>$ Diversity of Learners}

Learners have different learning styles, multiple intelligences, and needs. Information is preferentially taken in and processed in different ways: by seeing and hearing, reflecting and acting, reasoning logically and intuitively, analyzing, and visualizing steadily (Santrock, 2004). Studies concluded that teachers need to utilize learning styles and preferences in their instructions to meet the needs of learners. However, Noll (2001) insisted that the issue of multicultural education is complex and difficult. All of such account learners' diversity.

\section{$>$ Curriculum}

Since teachers must take into account the learning goals, then the instructional procedures and content must be explained to students. McMillan (2011) established a criterion for learning targets and standards. Learning targets must be set comprehensively. The targets must represent all types of important learning from the instructional unit. Knowledge targets should not be overwhelmed and must maintain balance among the five areas such as knowledge and simple understanding, deep understanding and reasoning, skills, products, and effect. Reliance on textbook objectives or the teacher's guide is not that very vital. Caga-anan (2012) supposed that the curriculum should be carefully selected and implemented so that the available time resources are effectively utilized. Only the most appropriate and pertinent subject areas should be included.

\section{$>$ Planning, Assessing and Reporting}

Ornstein, Lasley, and Mindes (2005) accounted that in teaching standards, the teacher plans instruction based on knowledge of the subject matter, students, the community, and the curriculum goals.

Garcia (2008) emphasized the fact that formative assessment is usually administered during the instructional process to provide feedback to students and teachers on how well the former modify instructions as needed. However, this type of test is not used for recording or grading, only for modification or adjustment of instructions. On the other hand, the summative evaluation must also be undertaken by the teacher to determine the rationale for passing or failing the students, based on a wide range of accumulated behaviors, skills, and knowledge. Hunt (2011) emphasized Gardner's view telling that assessment is typically done by engaging the children in an interesting task, rather than by formal testing. Studies have shown that children in kindergarten and the early elementary school years become more engaged when they participate in activities that suit their talents, than when they must conform to activities chosen for a class as a whole.

Vitriolo (2004) documented the need to submit students' grades without delay. It is one of the key obligations of teachers. A responsible teacher should be held answerable for failure to submit his/her student's grade or reports on performance on time within the reasonable time frame set by school authorities. These reports may be rendered through written communication or through notations at the back of the Report Card (Form 138) or any similar academic device which are given to students at the end of the grading period. 


\section{Community Linkages}

Bilbao, Corpuz, Llagas, and Salandanan (2006) professed that the school and the community are the mainsprings of effective and powerful forces that can create a wholesome climate for mutual gains and betterment. They can forge a kind of partnership where both are willing to share information as well as responsibilities to the best interest of the children while in school, likewise when dealing with members of the community. Parents from the community are ready to offer much-needed assistance in terms of resources while teachers are equally committed to spending time, effort, and expertise in serving the school children.

Besides, Estojero (2014) articulated Guerrero's study that schools could not be alone in all the responsibilities for the development of the sensitive human component in the community. Education will have to assume a new perspective that expands the school to the community and make it as a laboratory.

\section{$>$ Personal Growth and Professional Development}

Two (2) perspectives can be espoused for personal growth and professional development. The development of the profession and the professional identity that teacher educators share is one. It focuses on the individual teacher educator who is engaged in activities with a specific attitude, knowledge, and skills aiming at his/ her professional growth. Another is the focus on what individual teacher educator learns during work, the learning activities undertaken, and the reasons for learning at work. Pa-alisbo (2017) cited Corpuz \& Salandanan stating that to remain relevant and interesting, the teacher must possess 21st-century skills.

\section{$>$ Teaching Effectiveness}

Combate (2010) cited Cunningham and Allington who found out that management is not an isolated component of effective teaching. Effective teaching practice is a blend of appropriate teaching methodologies and classroom management practices that together create the environment for quality teaching-learning in the classroom and impact positively on student achievement.

\section{THEORETICAL FRAMEWORK}

One of the crucial issues raised today in education is not what the students should learn but rather how the students should learn. This study is guided by the Paradigm (from Transmission to Transactional) Shift of Education in the Philippines where the transfer of teaching concepts for Traditional "bookish and direct learning approach" Teaching into $21^{\text {ST }}$ Century Teaching focused on developing the learners higher-order thinking skills (Saice, 2009). Although NCBTS does not adhere to a single educational theory, it is a balanced framework that adopts assumptions of different educational theories. But underlying this framework is a core set of assumptions about teaching that is significantly different from traditional conceptions of teaching.

The new paradigm can be summarized by comparing it to traditional views. The traditional view says teaching is a technical process, and the good qualities of this process are well defined; teacher knowledge is technical knowledge applicable to all learners and contexts; teaching involves the consistent application of technical knowledge; and, effective application of teacher knowledge is dependent on prerequisite inputs in the teaching environment. Whereas in the NCBTS view, teaching is facilitating learning, and the qualities of good teaching are defined in terms of whether students learn or not; teacher knowledge is essentially complex and problematic; applicability varies across learners and contexts; teaching involves the reflective and flexible application of technical knowledge in ways the best brings about student learning, and effective teaching is determined within the limits and opportunities found in the learning environment. The domains such as diversity of learners, curriculum, and planning, assessing, and reporting are called good teaching. The learning environment and community linkages refer to the teaching practices that attempt to situate or at least link the teaching-learning process to the appropriate context of physical, psychological, and social in the classroom. Social regard for learning represents the ideal that the teacher serves as a model of all the positive values associated with learning. Personal growth and professional development represent the behaviors that dominate the teacher's actual aspirations to continue learning as a professional teacher (NCBTS, 2006).

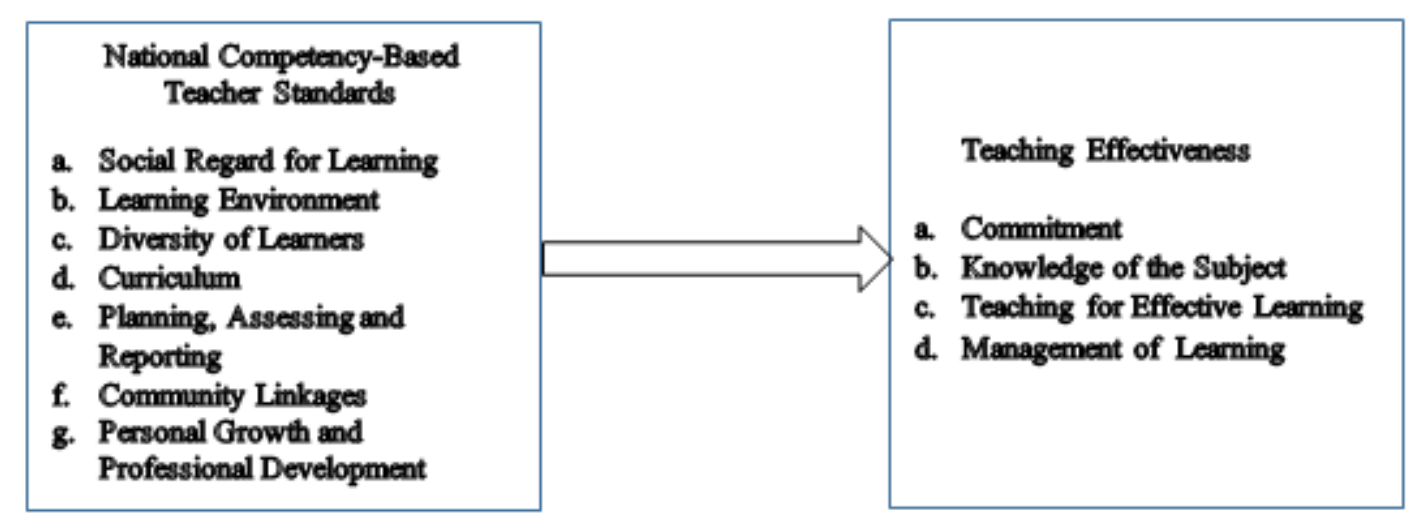

Fig 1:- Schematic structure showing the relationship of the independent variables and dependent variable 


\section{RESEARCH METHODOLOGY}

This section makes known of the methods and procedures used in collecting and treating the data. It gives details of sampling design, instrumentation, and statistical treatment of data.

\section{Sampling Design}

In determining the sample size of the study, which involved three (3) districts, the proportionate stratified random sampling method was the most appropriate means to use to derive an equal sampling fraction of each homogenous groups within strata.

\section{Instrumentation}

The questionnaire utilizing a five-point Likert Scale was divided into two (2) parts namely the adopted National Competency-Based Teacher Standards (NCBTS) Toolkit of which having been tested, Estojero (2014) derived a .955 Cronbach Alpha value reckoned to be highly reliable and valid measuring the level of teachers' competency in seven standard domains such as social regard for learning, learning environment, diversity of learners, curriculum, planning, assessing and reporting, community linkages, and personal growth and professional development; and the
Teacher Performance Evaluation Scale adopted from Central Mindanao University with Cronbach Alpha of .946 which is very reliable and valid according to Nietes (2013) measuring the level of teaching effectiveness as to commitment, knowledge of the subject, teaching-learning and management of learning.

\section{Statistical Treatment of the Study}

In determining the level of teachers' competency based on the National Competency-Based Teacher Standards in terms of social regard for learning, learning environment, diversity of learners, curriculum, planning, assessing and reporting, community linkages, and personal growth and professional development, mean data was presented. In ascertaining the level of teaching effectiveness of teachers according to commitment, knowledge of the subject, teaching for independent learning, and management of learning, percentage statistics was utilized. In establishing the significant relationship of teaching effectiveness and NCBTS, Pearson-Product Moment (Pearson-r) Correlation Coefficient data with probability level set as .05 were analyzed. Finally, in identifying the variable that singly or in combination best predict teaching effectiveness, Stepwise Multiple Regression data were examined.

\begin{tabular}{|c|c|c|}
\hline Competencies & Aggregate Mean & Descriptive Rating \\
\hline Social Regard for Learning & 3.83 & Proficient \\
\hline Learning Environment & 3.61 & Proficient \\
\hline Diversity of Learners & 3.58 & Proficient \\
\hline Curriculum & 3.87 & Proficient \\
\hline Planning, Assessing, and Reporting & 3.76 & Proficient \\
\hline Community Linkages & 3.88 & Proficient \\
\hline Personal Growth and Professional Development & 3.86 & Proficient \\
\hline
\end{tabular}

Table 1:- Level of teachers' competency based on the National Competency-based Teacher Standards (NCBTS)

\begin{tabular}{|c|c|c|c|}
\hline Range & Number of Units in Sample (n) & Percentage (\%) & Descriptive Rating \\
\hline $1.00-1.50$ & 0 & 0 & Poor \\
\hline $1.51-2.50$ & 1 & 19.15 & Fair \\
\hline $2.51-3.50$ & 36 & 68.09 & Satisfactory \\
\hline $3.51-4.50$ & 128 & 12.23 & Outstanding \\
\hline $4.51-5.00$ & 23 & \multicolumn{2}{c|}{ Satisfactory } \\
\hline
\end{tabular}

Table 2:- Level of teaching effectiveness of teachers

\begin{tabular}{|c|c|c|}
\hline Variables & Correlation Coefficient & p-value \\
\hline NCBTS & .211 & $.004 * *$ \\
\hline Social Regard for Learning & .304 & $.000^{* *}$ \\
\hline Learning Environment & .327 & $.000^{* *}$ \\
\hline Diversity of Learners & .445 & $.000^{* *}$ \\
\hline Curriculum & .235 & $.001^{* *}$ \\
\hline Planning, Assessing, and Reporting & .259 & $.000^{* *}$ \\
\hline Community Linkages & .301 & $.000^{* *}$ \\
\hline
\end{tabular}

ns - not significant

$* *-\mathrm{p}<.01$

$*-\mathrm{p}<.05$

Table 3:- Correlation between teaching effectiveness and NCBTS 
ISSN No:-2456-2165

\begin{tabular}{|c|c|c|c|c|c|}
\hline $\begin{array}{c}\text { Predictor } \\
\text { Variable }\end{array}$ & \multicolumn{2}{|c|}{$\begin{array}{c}\text { Unstandardized } \\
\text { Coefficient }\end{array}$} & $\begin{array}{c}\text { Unstandardized } \\
\text { Coefficient }\end{array}$ & t & Prob. \\
\hline & Beta & Std. Error & Beta & & \\
\hline (Constant) & 2.119 & .271 & & 7.831 & .000 \\
\hline Curriculum & .471 & .069 & .445 & 6.780 & .000 \\
\hline
\end{tabular}

$\mathrm{R}=0.445$

F-Value $=45.975$

$\mathrm{R}^{2}=0.198 \quad \mathrm{P}-$ Value $=.000$

Table 4:- Regression analysis on NCBTS against teaching effectiveness

\section{ANALYSIS AND INTERPRETATION OF RESULTS}

For problem number 1, among the seven (7) domains of NCBTS, community linkages (3.88) got the highest mean value described as 'proficient'. It was followed by the curriculum (3.87) in the second place, personal growth and professional development (3.86) in the third place, social regard for learning (3.83) in the fourth place, planning, assessing, and reporting (3.76) in the fifth place, learning environment (3.61) in the sixth place, and diversity of learners (3.58) in the seventh place.

For problem number 2, the level of teaching effectiveness as to commitment, knowledge of the subject, teaching for independent learning, and management of learning revealed that $12.23 \%$ of the teachers were outstanding, $86.09 \%$ were very satisfactory, $19.15 \%$ were satisfactory, only $0.5 \%$ were fair, and nobody was poor. The data project that the majority of the teachers perform very satisfactorily in their classroom. This further means that the teachers' performance meets and often exceeds the job requirement in teaching. This is possible

For problem number 3, all variables across NCBTS have significance to teaching effectiveness. Social regard for learning has a probability value of .004, and planning, assessing, and reporting have a probability value of .001 . The learning environment, diversity of learners, curriculum, community linkages, and personal growth and professional development have a probability value of .000 , which is highly significant. All of which is at .01 level of significance (2-tailed) rejecting the null hypothesis.

Finally, for the last problem, the curriculum was found to be the only predicting variable with .000 probability value deemed to be highly significant. The regression data exhibited the correlation coefficient (R) .445 as the aggregate correlational value between the incorporation of all independent variables (Xi's) and the dependent variable (Y) measuring the strength of their linear relationship. $\mathrm{R}^{2}$ is .918 giving the multiple determinations that explain the percentage to the variation of teaching effectiveness (Y) accounted for the curriculum as the predictor. Hence, $80.20 \%$ of the differences in teaching effectiveness were attributed to other factors. In has an F-value of 45.975 and a probability value of .000 on the ANOVA signifying significance of the regression model. Consequently, the null hypothesis was rejected. The regression connotes that as the $\mathrm{Y}$ increases, $\mathrm{X}$ also increases.

\section{DISCUSSIONS}

The findings of the study pointed out that as to the level of NCBTS in terms of social regard for learning, the teachers were 'proficient'. This is supported by the statement of Saymo as cited by Estojero (2014) that teachers by profession regardless of their ages and length of services rendered in an educational institution should at least be praised with proficient or highly proficient because teachers' performance has an incalculable impact on the pupils. Further, Gomez as cited by the latter recommends that teachers must always have a high-level instructional process which is measured by how they perform their tasks in the teaching-learning process.

As to the learning environment, the figures revealed that teachers were proficient. This result is in consonance to Marcia's (2010) analysis that classroom climate teachers establish for themselves and the students greatly affect the learning process. Yates mentioned that when classrooms are well-managed students can understand how to behave so that majority of the class time can be spent on instructional activities (Leone, 2009).

The teachers were proficient in dealing with the diversity of learners. This result is true to the statement of Salandanan (2006) that in a classroom setting the decision to employ individualized teaching method is anchored on a rationale that every student is unique and distinct beings, exhibits characteristics in ways of acting and speaking, thus reacts and constructs meanings in an unparalleled and inimitable manner.

The teachers were proficient in transmitting the curriculum. Teachers were able to perform a behavior that is satisfactory and is demonstrated almost all the time. All elements of the learning process that work in convergence to help students attain high standards of learning and understanding of the curricular goals and objectives were exhibited all the time. Such advocates Wiles' and Bondi's view as cited by Corpuz (2007) that if the curriculum is a plan for learning, then learning experiences need to be organized so that they serve the educational objectives of a school. Often, a curriculum is ineffective not because its content is ineffective but because learning experiences are organized in a way to prevent learning.

The teachers have a high value on planning the lessons, assessing the students' performance, and reporting these outcomes to the concerned stakeholders. This is in consonance to the finding of (Morphet, Johns and Reller (1982) who revealed that creative and appropriate 
instructional planning, use of non-traditional assessment techniques, use of assessment strategies and assessment strategies and assessment tools to monitor and evaluate learning, and results to improve teaching and learning, and keeping reporting of record of grades or performance level are exercised by the teachers almost all the time. Giving feedback and correctives on students as one of the six (6) teaching functions is recommended by Hoy and Miskiel (2001). It helps in maintaining interest and motivation further in the ongoing teaching-learning process (Mangal, 2007).

The proficiency of teachers in establishing community linkages was evident. This result agrees to the findings of Estojero (2014) who articulated that education would have to assume a new perspective that expands the school to the community and make it as a laboratory for teaching and learning.

Lastly, when it comes to personal growth and professional development, the teacher was found to be proficient. This result emphasizes that teachers have quite high repute on self-improvement as individuals and as professionals way that they have stature and behavior that uphold the dignity, read educational materials regularly, participate in educational seminars and workshops, and engage in educational research, possess one's philosophy of teaching, have professional linkages, and reflect on the quality of their teaching. Malinda (2014) found out that teachers have met varied problems on the promotional practices based on criteria as such ranked the topmost is a financial constraint, difficulty in producing supporting documents, misinformation on the guidelines to be outstanding teachers, lack of courage to establish linkages, and lack of courage to lead a group. The result is guided by Pateño's (2012) study that cited Carr stressing about professional and educational change as two (2) strongly related factors.

Most of the teachers were found to be very satisfactory in their teaching effectiveness. A few were only satisfactory and very satisfactory, respectively. This is possible because even a good teacher, according to Gregorio as declared by Dua (2003), is not necessarily born with teaching instinct, then he has been a product of years of effort so that it is gained through hard work and genuine desire to improve oneself. Such is supported by Orilla as mentioned by Delos Santos (2014) that some of the teachers' qualities bearing on the conditions of teaching effectiveness include intelligence, aptitude for teaching, character, health, emotional stability, and attractiveness.

The seven (7) domains of NCBTs were found to be highly correlated to teaching effectiveness. This is why Aquino (2003) suggested that there should be a corollary concern on the giving of adequate training of enough personnel who will be tasked with researching the various aspect of teaching effectiveness. Perhaps an appropriate division could be established in the Department of Education to take the lead in the research activities and monitor research efforts in the learning institutions. Thus, the true test of quality teaching is the degree to which one can improve the quality of life (Calonge, 2007).

Of all the domains stated beforehand, the only curriculum garnered a highly significant probability value making it the single predictor of teaching effectiveness. These explicit notions that teachers having executed the curriculum to a high degree of proficiency in the education system are understood to have given a positive and powerful model in the pursuit of different efforts to learn; and maintained a pleasant learning environment providing social, psychological, and physical environment. With the findings, regression data indicates that teaching is highly proficient when teachers have the expertise and thorough knowledge in transmitting and implementing the curriculum. When teaching effectiveness escalates, apparently transmitting the curriculum also escalates, and so with the rest of the domains in NCBTS.

\section{CONCLUSIONS}

Therefore, the teachers equipped with the National Competency-Based Teacher Standards in terms of social regard for learning, learning environment, diversity of learners, curriculum, planning, assessing and reporting, community linkages, and personal growth and professional development were found to be proficient. Most of the teachers were very satisfactory in terms of teaching effectiveness. All the NCBTS domains are correlated to teaching effectiveness, and curriculum is the predictor teaching effectiveness.

\section{RECOMMENDATIONS}

Based on the findings, several propositions have been formulated. The in-service teachers may attend more training, seminars, and relevant conferences to acquire more teaching skills and exhibit mastery in teaching all the learning areas in the $\mathrm{K}$ to 12 Curriculum. They may enroll in a graduate degree program to advance their proficiency. The teachers may have absolute execution of the seven (7) domains to sustain and even escalate their competency. Since, NCBTS is specially designed for pre-service teachers, all the competencies must be acquired beforehand. Further, it is proposed that the Professional Regulation Commission (PRC) design the Licensure Examination for Teachers (LET) based on the NCBTS. For plotters of seminars, training, and conferences, the findings may serve as a baseline for them to design and conduct a protracted yearly seminar-workshops on the implemented curriculum for in-service teachers. 


\section{REFERENCES}

[1]. P. P. Bilbao, B. B. Corpuz, A.T. Llagas, G. G. Salandanan, The teaching profession, Adriana Printing Corporation, Inc., 776 Aurora Blvd. Cor. Boston Street, Cubao Quezon City.Metro Manila, 2006.

[2]. D. C. Calonge, JR. Teaching competencies of music, arts and physical education (MAPE) teachers. Unpublished Master's Thesis, Bukidnon State University Malybalay City, 2007.

[3]. L. D. T. Combate, Causal models of teacher productivity in the department of education, division of Bukidnon, Unpublished dissertation, Central Mindanao University, 2010.

[4]. B. B. Corpuz, G. G. Salandanan, Principles of Teaching 1, 2007.

[5]. F. J. Delos Santos, Professional development practices of public elementary school teachers Unpublished Master's Thesis, Bukidnon State University, Malaybalay City, 2014.

[6]. R. C. DUA, Competencies of public elementary school teachers in teaching edukasyong pantahana at pangkabuhayan (epp), Unpublished Master's Thesis, Central Mindanao University, Musuan Maramag Bukidnon, 2003.

[7]. A. Q. Estojero, Mother tongue-based multilingual education: an assessment in teaching strategies, teacher's attitudes and performance, unpublished Master's Thesis, Central Mindanao University, Musuan Maramag Bukidnon, 2014.

[8]. D. D. Garcia, Measuring and evaluating learning outcomes: a textbook in assessment of learning, Mandaluyong, Philippines: Book Atbp., Publishing Corporation, 2008.

[9]. Harington, R. G. Holub, L. Taking sides: clashing views on controversial classroom management. Dubuque; Iowa: McGraw 2006.

[10]. W. K. Hoy, C. G. Miskel, Educational administration theory, research and practice, Mcgraw-Hill international edition, New York: McGraw-Hill Companies, Inc., 2001.

[11]. E. Hunt, Human intelligence, Cambridge, New York: Cambridge University Press, 1, 2011.

[12]. Kentucky Department of Education, Characteristics of highly effective teaching and learning (check), retrieved from http://education.ky.gov/curriculum/docs/pages/charact eristcs-of-hihgly-effective-teaching-nd-learning$\% 28$ chet1\%29.aspx, 2013.

[13]. V. Labrador, National Competency-Based Teacher Standards Toolkit, open letter, 2013.

[14]. E. Malinda, Awareness of public school teachers on promotional practices, Unpublished Master's Thesis, Bukidnon State University, Malaybalay City, 2014.

[15]. S. K. Mangal, Essentials of Educational Psychology, Prentice: Hall of India, Pct. Ltd., New Delhi, 256; 248; 175; 185, 2007.

[16]. S. Mateo, DepEd, UNESCO unveiled the latest EFA global monitoring report, retrieved from www.deed.gov.ph/press-releases/deped-unescounveil-latest-efa-global-monitoring-report, 2014.
[17]. J. H. McMillan, Classroom assessment principles and practices for effective standards-based instruction. Boston MA, USA: Pearson Education Incorporated Publishing as Allyn and Bacon, p. 29, 2001.

[18]. E. L. Morphet, R. L. Johns, T. L. Reller, Educational organization and administration concepts, Inc. Reprinted: Caloocan, Metro Manila: Philippines Graphic Arts, Inc., 1982.

[19]. National Competency-Based Teacher Standards Toolkit, DepEd, TEPD technical working group, basic education reform agenda, DepEd Complex, Meralco, Avenue, Pasig City 1600, 2013.

[20]. National Competency-Based Teacher Standards, A professional development guide for the Filipino teachers, department of education, retrieved from http://www.slideshare.net/mamalixuss/ncbtsnationalcompetencybased-teachers-standards-2013, 2006.

[21]. M. H. Nites, epistemological beliefs, self-efficacy, leadership capacity and performance of STEM teachers: a multi-method exploration, dissertation, Central Mindanao University, Musuan Maramag Bukidnon, 2013.

[22]. J. Wm. Noll, Taking sides: clashing views on controversial education issues, 11th edition, 5:127, 2001.

[23]. A. C. T. Ornstein, T. T. Lasley, G. Mindes, Secondary and middle school methods, Boston, USA: Pearson Education Incorporated, p. 74, 2005.

[24]. M. A. C. Pa-alisbo, The 21st Century Skills and Job Performance of Teachers, retrieved from https://files.eric.ed.gov/fulltext/ED578609.pdf, 2017.

[25]. G. B. Pateño, Self-efficacy of elementary school teachers: effects on their teaching performance, Unpublished Master's Thesis, Central Mindanao University, Mususan Maramag Bukidnon, 2012.

[26]. B. Saice, Filipino teachers for the 21st century, teacher education and 21st-century skills, retrieved from

http://www.saicebrian.wordpress.com/2009/07/05/nati onal-competency-based-teacher-standards-ncbts, 2009.

[27]. G. G. Salandanan, Elements of Good Teaching, Quezon City, Philippines: Katha Publishing, p. 50-77, 2006.

[28]. J. W. Santrock, educational psychology 2nd edition, p. 21, 26, 2004.

[29]. J. Vitriolo, Teacher's problems n grading students, part I, the Philippine Journal of Education, Milestone in Philippine education establishments of mission schools, volume LXXXII, number 1:27, 2004. 